Vol. 2, No. 2, 2015

\author{
O. Ye. Kuzmin \\ Doctor of Economics, Professor,
} O. H. Melnyk

Doctor of Economics, Professor,

O. V. Mukan

$\mathrm{PhD}$ of Economic Sciences, as. prof.,

M. Ye. Adamiv

$\mathrm{PhD}$ of Economic Sciences,

Lviv Polytechnic National University

\title{
CONTRADICTIONS OF THE NATIONAL LEGAL AND REGULATORY FRAMEWORK IN THE FIELD OF SOCIO-ECONOMIC DIAGNOSING IN CONDITIONS OF EUROPEAN INTEGRATION
}

\begin{abstract}
The article analyzes the national legal and regulatory framework in the field of socio-economic diagnosing of the major parameters and operation directions of the objects being diagnosed such as financial conditions, the threat of bankruptcy, solvency (credit status), and investment attractiveness. Based on the results obtained there are singled out, generalized and justified the key contradictions of national regulations governing principles of assessing the priority sectors of these objects operation. The importance of further development of the national legal and regulatory support of socio-economic diagnosing towards its unification in modern conditions of European integration is proved.

In terms of revitalization of European integration processes in Ukraine and globalization processes in the world the importance of socio-economic diagnosing at all levels of national and international economies is increasing. In fact, successful establishment and further development of relationships between domestic and foreign partners at different levels (state authorities, financial, credit and insurance institutions, rating agencies, securities market participants, investors, intermediaries, contractors, businesses) require accurate, representative and objective database obtained through target diagnosing. Recently stakeholders have been primarily interested in socio-economic diagnosing of such aspects of particular entities as financial conditions, threat of bankruptcy, solvency, investment attractiveness etc. Target diagnosing is based on various techniques developed by the legislative authorities of Ukraine that are still being used to form special methodological guidelines for evaluating priority operation areas of the diagnosed objects. Obviously, the methodological provisions reflected in the current national legal and regulatory framework should be standardized and unified for all users in both domestic and international environment to ensure exclusive regulation of key principles of socio-economic diagnosing and unified
\end{abstract}

interpretation of the diagnostic results. Unfortunately, at present in the national legal and regulatory framework there are many problems associated with discrepancies, inconsistencies and contradictions of certain diagnostic methods. Considering all the above, there arises the necessity to study current national legislation and regulatory materials to identify existing conflicts in the area of socio-economic diagnosing.

Key words: socio-economic diagnosing, European integration, legal and regulatory framework, contradictions, methods, indicator, criterion.

Review of literature. The results of studying different aspects of the national legal and regulatory framework in the field of socio-economic diagnosing and the suggestions for its improvement are reflected in the works of domestic scientists [1-4] and others. Typically, the authors reveal the problems of socio-economic diagnosing regulatory support only in certain operating areas of the object being dignosed. Thus, today there are almost no developments, which would comprehensively reflect the key problem points in the national regulatory framework of socio-economic diagnosis in all priority areas of evaluation in conditions of European integration. In addition, the legislative bodies often make various changes and additions to certain documents regulating the basics of implementing diagnostic procedures. This, in turn, makes the perevious research quickly lose its relevancy causing the necessity of permanent keeping the track and analyzing all the changes and innovations in the national legal and regulatory framework in the field of socio-economic diagnosing. Identification of principal contradictions in the legal and regulatory support of socio-economic 
diagnosing and its consequent reformation in the modern period of active European integration of Ukraine has particular relevance. This will ensure not only solution of the existing problems at the national level but will also increase the international prestige of Ukraine and facilitate dynamic integration of Ukraine into European economic environment.

The purpose of the article. Taking into account the relevancy of the researched issues in modern conditions of Ukraine's European integration as well as the results of the literature analysis [1-4], the authors set as the purpose of the article the deep analysis of the valid national legal and regulatory acts that regulate principal fundamentals of socio-economic diagnosing along the priority evaluation directions and justification of the main contradictions in these acts.

Research materials. The European vector of the national economic development envisages deepening of cooperation between different domestic and foreign actors of micro-, mezzo- and macro-environment (government authorities, financial and credit institutions, investors, intermediaries, counter-agents, business structures). The foreign partner's decision to initiate cooperation with a domestic entity as well as the nature of further relationships with it are basically affected by the substantial information base obtained through the target diagnosing of different aspects of the entity's activities.

Thus, socio-economic diagnosing is forming information foundation for establishing, maintaining and expanding the relationships among different actors of micro-, mezzo-, and macro-environment at the national and international levels, first of all, in the context of revitalizing European integration processes in Ukraine. Unfortunately, in practice, there exist the situations when the results of simultaneous diagnosing of identical entities performed by different domestic and international stakeholders bring absolutely different, disproportionate results, different identification and interpretation of the entities conditions. This, in turn, substantially hinders the creation of efficient relationships between domestic and foreign partners.

Such a situation is caused by a number of factors, among them: non-compliance of the regulatory framework provisions concerning indicators and criteria as well as identification and interpretation support of socio-economic diagnosing; unsubstantiated criteria of diagnostic indicators optimization with the account of the domestic economy realities; the variety of methods applied to diagnosing of identical objects (thus, only in the sphere of financial conditions diagnosing there are about two dozens of methods used in legal framework and about fifty methods described in educational and research literature) etc. The majority of regulatory documents present economically ungrounded and meaningless evaluation indicators, duplicating and reciprocal indicators, and unjustified criteria, ambiguous and subjective methods of diagnosis, outdated information provision. In the areas of socio-economic diagnosing regulated by the regulatory framework it is quite common to obtain inadequate data not reflecting and sometimes even distorting information about the real state of the object being diagnosed. Besides, in non-normalized spheres, the stakeholders performing diagnosis can manipulate the results through applying more favorable methods and criteria, and this again leads to distortion of the information picture.

During the history of independent Ukraine there was developed and ratified quite a number of legal and regulatory documents regulating the principles of socio-economic diagnostics of various micro-, mezzo-, and macro-environment objects functioning. The majority of legislation and regulatory materials deals with activities assessment of enterprises with different ownership forms. Thus, in modern conditions of Ukraine's active integration into the European economic environment it is required to pay special attention to the legal and regulatory documents related to diagnosing the priority operation areas of domestic economic entities. We mean that the financial conditions should be evaluated as the key parameter determining the enterprise efficiency, its solvency should be assessed as the basis for identifying the class of borrower, and, consequently, the possibility of its access to credit resources, the threat of bankruptcy is assessed with the aim to prevent and overcome the crisis situation, and the investment attractiveness is evaluated for determining the expediency of making investments etc. So, it is expedient to consider and analyze the basic domestic legal and regulatory documents presenting the appropriate methods for diagnosing the above presented operation areas of enterprises with the aim to identify the drawbacks and contradictions in 
the sphere of socio-economic diagnosing. This will allow to form the universal base for unification and standardization of diagnostic methods, indicators and criteria. In the sphere of diagnosing the financial conditions and the threat of bankruptcy of economic entities the key regulatory documents are "Methodical recommendations concerning identification of the signs of the enterprise insolvency and the features of the actions signaling concealment of bankruptcy, false bankruptcy or incitement to bankruptcy" approved by the Order of the Ministry of Economy of Ukraine No.14 of January 19, 2006 (with amendments and additions), "The procedure of analyzing financial and economic conditions of economic entities of public enterprises and the enterprises in which the share of state ownership in the authorized capital exceeds fifty percent; and preparation of conclusions about the presence of the signs of false bankruptcy, incitement to bankruptcy, concealment of stable financial insolvency, unlawful actions in case of bankruptcy at the request of the court, public prosecutor's office or any other authorized body" approved by the Ministry of Justice of Ukraine № 327/5 of February 26, 2013 (with amendments and additions), "Methods of profound analysis of financial and economic conditions of insolvent enterprises and organizations" approved by the Order of the Agency on Preventing Bankruptcy of Enterprises and Organizations № 81 of June 27, 1997, "Methodical recommendations on analysis of financial and economic conditions of enterprises and organizations" (The Letter of the State Tax Administration of Ukraine № 759/10/20-2117 of January 27, 1998 [5-8] and others. These are substantial documents reflecting concrete indicators and formulas for their calculation with the reference to information sources for obtaining data, and the appropriate normative criteria. But the key problem of applying the provisions of these documents in practice is related to the fact that all of them are characterized by the obsolete information support of the diagnosing that will not result in appropriate accounting reporting. Besides, the developed methods of diagnosing in some of the named documents are overloaded with indicators, some of them being interrelated, interdependent and reciprocal and this demonstrates the necessity of optimizing their quantity based on including only the most representative and simple, as to the necessity of their information support, calculations.
In particular, "Methodical recommendations concerning identification of the signs of the enterprise insolvency and the features of the actions signaling concealment of bankruptcy, false bankruptcy or incitement to bankruptcy" approved by the Order of the Ministry of Economy of Ukraine № 14 of January 19, 2006 (with amendments and additions) [7] are based on the analysis of about 50 absolute and relative indicators, and contain mostly economically insignificant indicators, the indicators that are identical as to the formula of their calculation but have different names, the indicators that are characterized by absolutely incomplete and ungrounded criteria base, shallow interpretation and identification pool that does not account all the operating areas of the diagnosed enterprise necessary for obtaining the adequate results but mainly concentrates on the evaluation of the entity's profitability. Besides, these Methodical Recommendations form the basis for arbitration managers to manipulate the diagnosis results concerning the threat of the enterprise bankruptcy and allow them to adopt lobbied judgments because some indicators have no criteria value at all, while others have absolutely unsubstantiated criteria.

It is worth mentioning that in "The procedure of analyzing financial and economic conditions of economic entities of public enterprises and the enterprises in which the share of state ownership in the authorized capital exceeds fifty percent; and preparation of conclusions about the presence of the signs of false bankruptcy, incitement to bankruptcy, concealment of sustainable financial insolvency, unlawful actions in case of bankruptcy at the request of the court, public prosecutor's office or any other authorized body" approved by the Ministry of Justice of Ukraine № 327/5 of February 26, 2013 (with amendments and additions) [8] there is no concrete indicatorscriteria base for diagnosing financial and economic conditions of public enterprises that would be absolutely applicable to such economic entities given the specifics of their legal form.

There exist quite a number of problems in the sphere of diagnosing the solvency (credit status) of enterprises. Thus, in "Regulations on the procedure of formation and use of the reserves for reimbursement of possible losses on active banking operations by the banks of Ukraine" approved by the Resolution of the Management Board of the National Bank of Ukraine № 23 of January 25, 
2012 (with amendments and additions) [9] there are presented different models for calculating the integral indicator of the debtor-legal entity depending upon the type of their business activity and the size that are based only on calculating the quantitative indicators and do not take into account the indicators that characterize credit support, the enterprise credit history, its responsibility. Such an approach fails to provide banks with the chance to adequately identify the class of the borrower as it ignores the individual characteristics of the previous, current and perspective activities of each particular enterprise in the credit sphere.

As to diagnosing the investment attractiveness, the key regulatory document in this sphere is "Methods of integral evaluation of investment attractiveness of enterprises and organizations" approved by the Order of the Agency on Preventing Bankruptcy of Enterprises and Organizations № 22 of February 23, 1998 [10]. The major drawbacks of the presented methods are: they are based on the accounting system that does not exist; they use more than 60 diagnostic indicators, it being inappropriate given their interdependence and content identity; they contain no recommendations on the interpretation of the results obtained.

All the above presented problems of contradictory character in the national legal and regulatory framework in the sphere of socioeconomic diagnosing require immediate solutions at the national level on the basis of formation and improvement of unified methodical recommendations on elimination of the existing contradictions, economic incorrectness and inappropriateness concerning indicators-criteria and identification-interpretation support of socio-economic diagnosing.

Conclusions. On its way to European integration Ukraine unprecedentedly expands its cooperation with EU countries in different spheres, first of all, in the socio-economic sphere. The key priority in this situation is the development of unified objective and substantiated legal and regulatory framework to be used for socioeconomic diagnosing by both national and international subjects at all levels of national and international economies to overcome various barriers and to ensure conflict-free relationships. Really, to guarantee the establishment of any cooperation it is necessary to develop single highquality unified information base available to all its users. Unfortunately, at present the valid national legal and regulatory framework in the sphere of socio-economic diagnosing is characterized by essential contradictions and inconsistencies, lack of uniformity and versatility in diagnosing identical entities. The national diagnostic methods are incomplete, ungrounded and not adjusted to international standards. All these drawbacks lead to obtaining inappropriate, non-correlating, and disparate results of diagnosing at national and international levels and this fact greatly hinders the efficiency of cooperation between national and international diagnosing subjects. The solution of these problems, elimination of any manipulations with the diagnosing results, obtaining comparable, complete and reliable results on the diagnosed entity operation can be possible on the basis of unification of regulatory-methodological, indicatorscriteria, identification-interpretation support of socio-economic diagnosing at the national level. Thus, further research can deal with the development of methodical recommendations on socio-economic diagnosing at micro-, mezzo-, and macro-levels of national and international economies, being universal, uniform and harmonized with the international standards and being based on justified indicatorscriteria and identification-interpretation support of the diagnosing process with the account of modern challenges of European integration processes in Ukraine.

\section{References}

1. Mieshkov A. V. Udoskonalennia instrumentiv otsinki investytsiinoi pryvablyvosti pidpryyemstva u vidpovidnosti do suchasnykh problem rynku $i$ zmin chynnoho zakonodavstva [Improvement of enterprise investment attractiveness in accordance with modern market problems and current legislation changes] / A. V. Mieshkov, O. Yu. Mentel // Problems of Economics. Economics and Enterprise Management. 2014. - № 4. - P. 298-304.

2. Raikovska I. T. Problemy zastosuvannia metodyk analizu finansovoho stanu $v$ diyalnosti promyslovyh pidpryyemstv [Problems of applying methods of analyzing financial conditions in industrial enterprises activities] / I. T. Raikovska // Collection of Scientific Works of ZhDTU. Economic Sciences. 2009. - № 3(49). - P. 154-158.

3. Chaikovskyi Ya. Napriamky vdoskonalennia metodyky analizu kredytospromozhnosti borzhnyka yurydychnoi osoby [Directions of improving methods of analyzing solvency of debtor-legal entity] / Ya. Chaikovskyi // Issue 19(1). - 2014. P. 176-188. 
Contradictions of the national legal and regulatory framework in the field of socio-economic diagnosing...

4. Chernysh S. S. Ohliad metodyk analizu investytsiinoi pryvablyvosti pidpryyemstva [Review of methods of analyzing enterprise investment attractiveness] / S. S. Chernysh. - 2013. - № 5(43). P. 87-92.

5. Metodyka provedennia pohlyblenoho analizu finansovo-hospodarskoho stanu neplatospromozhnyh pidpryyemstv ta orhanizatsii zatverdzhena Nakazom Ahentstva $z$ pytan zapobihannia bankrutstvu pidpryyemstv ta orhanizatsii \# 81 vid 27.06.1997 [Methods of profound analysis of financial and economic conditions of insolvent enterprises and organizations approved by the Order of the Agency on Preventing Bankruptcy of Enterprises and Organizations № 81 of June 27, 1997]. Available at: http://www.rada.gov.ual

6. Methodical recommendations on analysis of financial and economic conditions of enterprises and organizations" (The Letter of the State Tax Administration of Ukraine № 759/10/20-2117 of January 27). Available at: http://pro-u4ot.info/index.php? section= browse \&CatID $=156 \&$ Art ID $=422$

7. Methodical recommendations concerning identification of the signs of the enterprise insolvency and the features of the actions signaling concealment of bankruptcy, false bankruptcy or incitement to bankruptcy" approved by the Order of the Ministry of Economy of Ukraine № 14 of January 19, 2006 (with amendments and additions). Available at: http://search.ligazakon.ua/l_doc2.nsf/linkl/

ME06025.html

8. The procedure of analyzing financial and economic conditions of economic entities of public enterprises and the enterprises in which the share of state ownership in the authorized capital exceeds fifty percent; and preparation of conclusions about the presence of the signs of false bankruptcy, incitement to bankruptcy, concealment of sustainable financial insolvency, unlawful actions in case of bankruptcy at the request of the court, public prosecutor's office or any other authorized body" approved by the Ministry of Justice of Ukraine № 327/5 of February 26, 2013 (with amendments and additions). Available at: http://www.rada.gov.ual

9. Regulations on the procedure of formation and use of the reserves for reimbursement of possible losses on active banking operations by the banks of Ukraine approved by the Resolution of the Management Board of the National Bank of Ukraine № 23 of January 25, 2012 (with amendments and additions). Available at: http://www.rada.gov.ual

10. Methods of integrated assessment of investment attractiveness of enterprises and organizations approved by The Order of the Agency on Prevention of Bankruptcy of Enterprises and Organizations. № 22 of February 23, 1998. Available at: http://www.rada.gov.ual 
